\title{
A Study of Low-Potential Heat Utilization Methods for Oxy-Fuel Combustion Power Cycles
}

\author{
Andrey Rogalev ${ }^{1}$, Nikolay Rogalev ${ }^{2}$, Vladimir Kindra ${ }^{1, *(1)}$, Olga Zlyvko ${ }^{1}$ and Andrey Vegera ${ }^{1}$ \\ 1 Department of Innovative Technologies of High-Tech Industries, National Research University “Moscow \\ Power Engineering Institute", 111250 Moscow, Russia; rogalevan@mpei.ru (A.R.); zlyvkoov@mpei.ru (O.Z.); \\ vegeraan@mpei.ru (A.V.) \\ 2 Department of Thermal Power Plants, National Research University "Moscow Power Engineering Institute", \\ 111250 Moscow, Russia; rogalevnd@mpei.ru \\ * Correspondence: kindravo@mpei.ru
}

Citation: Rogalev, A.; Rogalev, N.; Kindra, V.; Zlyvko, O.; Vegera, A. A Study of Low-Potential Heat

Utilization Methods for Oxy-Fuel Combustion Power Cycles. Energies 2021, 14, 3364. https://doi.org/ $10.3390 /$ en14123364

Academic Editor: Jaroslaw

Krzywanski

Received: 27 April 2021

Accepted: 4 June 2021

Published: 8 June 2021

Publisher's Note: MDPI stays neutral with regard to jurisdictional claims in published maps and institutional affiliations.

Copyright: (c) 2021 by the authors. Licensee MDPI, Basel, Switzerland. This article is an open access article distributed under the terms and conditions of the Creative Commons Attribution (CC BY) license (https:/ / creativecommons.org/licenses/by/ $4.0 /)$.

\begin{abstract}
The world community is worried about the effects of global warming. A few agreements on the reduction of $\mathrm{CO}_{2}$ emissions have been signed recently. A large part of these emissions is produced by the power production industry. Soon, the requirements for thermal power plant ecology and efficiency performance may become significantly higher. Thus, the contemporary problem is the development of highly efficient power production facilities with low toxic and greenhouse gas emission. An efficient way to reduce $\mathrm{CO}_{2}$ emissions into the atmosphere, which implies maintaining economic growth, is the creation of closed thermodynamic cycles with oxy-fuel combustion. The Allam cycle is one of the most promising among oxy-fuel power plants. A 50 MW pilot Allam cycle plant was built in Texas. The design for a commercial system with an electrical output of $300 \mathrm{MW}$ is under development. This work is devoted to the improvement of the efficiency and environmental safety of oxy-fuel combustion power cycles via the utilization of compressed working fluid heat. The results of computer simulation obtained using AspenONE software demonstrated that an additional circuit in the multi-flow regenerator might increase net efficiency by $3.5 \%$. Besides this, the incorporation of a supercritical carbon dioxide $\left(\mathrm{S}-\mathrm{CO}_{2}\right)$ Brayton cycle with recompression increased the efficiency by $0.2 \%$. Therefore, the maximum net efficiency of the prospective power unit was $51.4 \%$.
\end{abstract}

Keywords: oxy-fuel combustion power cycle; carbon dioxide capture and storage; low-potential heat; air separation unit; thermodynamic optimization; net efficiency

\section{Introduction}

Available power and the growth rate of electricity production are important factors in economic development. In recent decades, renewable power sources have grown rapidly, but the majority of heat and electricity are still produced by the combustion of organic fuels. This tendency will probably remain, for technical and financial reasons [1,2].

The environmental safety of thermal power plants operating with organic fuel may be remarkably improved by a transition to oxy-fuel combustion power cycles, with carbon dioxide as a working fluid [3-5]. The key elements of the prospective power generation technology are an oxy-fuel combustion chamber and carbon dioxide capture and storage (CCS) systems. Reviews of the different oxy-fuel combustion power cycles have shown that the most effective is the Allam cycle [6-8]. Its net efficiency could be above 50\% $[9,10]$.

The Allam cycle is a supercritical, $\mathrm{CO}_{2}$ Brayton cycle with oxy-fuel combustion and recuperation. NET Power and 8 Rivers Capital, together with Toshiba, CB\&I, and Exelon, developed a $50 \mathrm{MW}$ Allam cycle plant in Texas. The design for a commercial system with an electrical output of $300 \mathrm{MW}$ is under development. The main challenges in scaling up the system are the development of a high-pressure, oxy-fuel combustor operating in a wide pressure range [11], which is a compact, multi-stream heat exchanger, the design of which 
provides high thermal cycle efficiency and moderate expenses for heat resistant alloys [12]. Partial load regimes also should be considered before the implementation of a high-power, oxy-fuel power plant [13].

The preferable fuel allowing for achieve maximum efficiency for the Allam cycle is natural gas. Nevertheless, world coal resources are three times larger than natural gas ones $[14,15]$ and therefore, the development of coal-fired power generation units with nearzero emissions is also a promising direction. A possible means for the transition to solid fuels in the oxy-fuel combustion cycle is gasification. According to the modeling results presented in [16], an implementation of gasification technologies remarkably reduced power plant thermal efficiency.

In particular, the Allam cycle with coal gasification and use of syngas sensible heat in an additional steam turbine cycle compared with an integrated gasification combined cycle (IGCC) in the paper [17]. The Allam cycle net efficiency was 39.6\%, which was a little lower than the $40 \%$ net efficiency value of the IGCC without $\mathrm{CO}_{2}$ capturing. However, nearly complete carbon capture is the Allam cycle's advantage against the IGCC.

Papers $[18,19]$ disclose the efficiency of the Brayton cycle with supercritical $\mathrm{CO}_{2}$, which uses the sensible heat of syngas in the Rankine steam cycle. This cycle, with $98.1 \%$ $\mathrm{CO}_{2}$ capture, has $40.6 \%$ net efficiency. IGCC, based on the same gasifier, captures about $90 \%$ of $\mathrm{CO}_{2}$ and has $31.2 \%$ net efficiency. Thus, the transition to oxy-fuel combustion power cycles is reasonable from the points of view of efficient power production and environmental safety.

Investigations $[20,21]$ propose the Allam cycle with coal gasification, wherein syngas sensible heat is used for power production in an additional carbon dioxide back-pressure turbine, and the turbine exhaust gas is supplied to a multi-flow regenerator. This technical solution allows cycle net efficiency of $43.7 \%$ at a carbon dioxide turbine inlet temperature of $1200{ }^{\circ} \mathrm{C}$.

Numerous investigations have been concerned with the optimization of the Allam cycle's parameters. The thermodynamic studies presented in [22-24] showed that the power facility reached its maximal efficiency at the following parameters: initial temperature and pressure of $1083{ }^{\circ} \mathrm{C}$ and $30 \mathrm{MPa}$, final pressure of $3 \mathrm{MPa}$, and cooling agent temperature of $200{ }^{\circ} \mathrm{C}$. The prospective oxy-fuel combustion power cycle achieved $8.5 \%$ higher efficiency and 11-12-fold lower carbon dioxide emissions than the combined cycle facility with CCS.

Zhu Z. and Chen Y., et al. [25] discussed modifications to the Allam cycle, whereby the $\mathrm{CO}_{2}$ was compressed with pumps instead of compressors, which resulted in a $2.96 \%$ facility net efficiency improvement, up to $50.87 \%$. Fernandes D. and Wang S., et al. [26] are devoted to exploring the influence of the type of oxidizer compression machine on the oxy-fuel facility's efficiency.

An important feature of the Allam cycle is the integration of the air separation unit (ASU) into the cycle of supplying compressed hot air into the regenerative heat exchange system. That said, the utilization of low-potential heat sources, including the flow energy, in different compressors, has not yet been investigated. Therefore, this investigation aims to develop a highly efficient, oxy-fuel combustion power cycle that utilizes low-potential heat sources.

\section{Research Objectives}

This investigation's starting point is the Allam cycle, wherein the low-potential heat of the ASU's compressed air is used in a multi-flow heat exchanger. The main working fluid component of the cycle is carbon dioxide.

The cycle presented in Figure 1 operates as follows: The combustor is supplied with three flows, the fuel gas $\left(\mathrm{CH}_{4}\right)$ is compressed in the fuel compressor, the oxidizer is produced in the ASU and compressed in the oxygen compressor, and the working fluid is heated in the multi-flow regenerator. The combustion of the oxy-fuel mixture in the carbon dioxide environment creates high-temperature products that enter the carbon dioxide turbine. These products drive the power generator and then enter the multi-flow 
regenerator, where they transfer some heat to the heated flows. Next, the flow is directed to the cooler-separator, where water and $\mathrm{CO}_{2}$ contents are split. After the cooler-separator, part of the carbon dioxide flow is compressed to supercritical pressure and is then sent to storage.

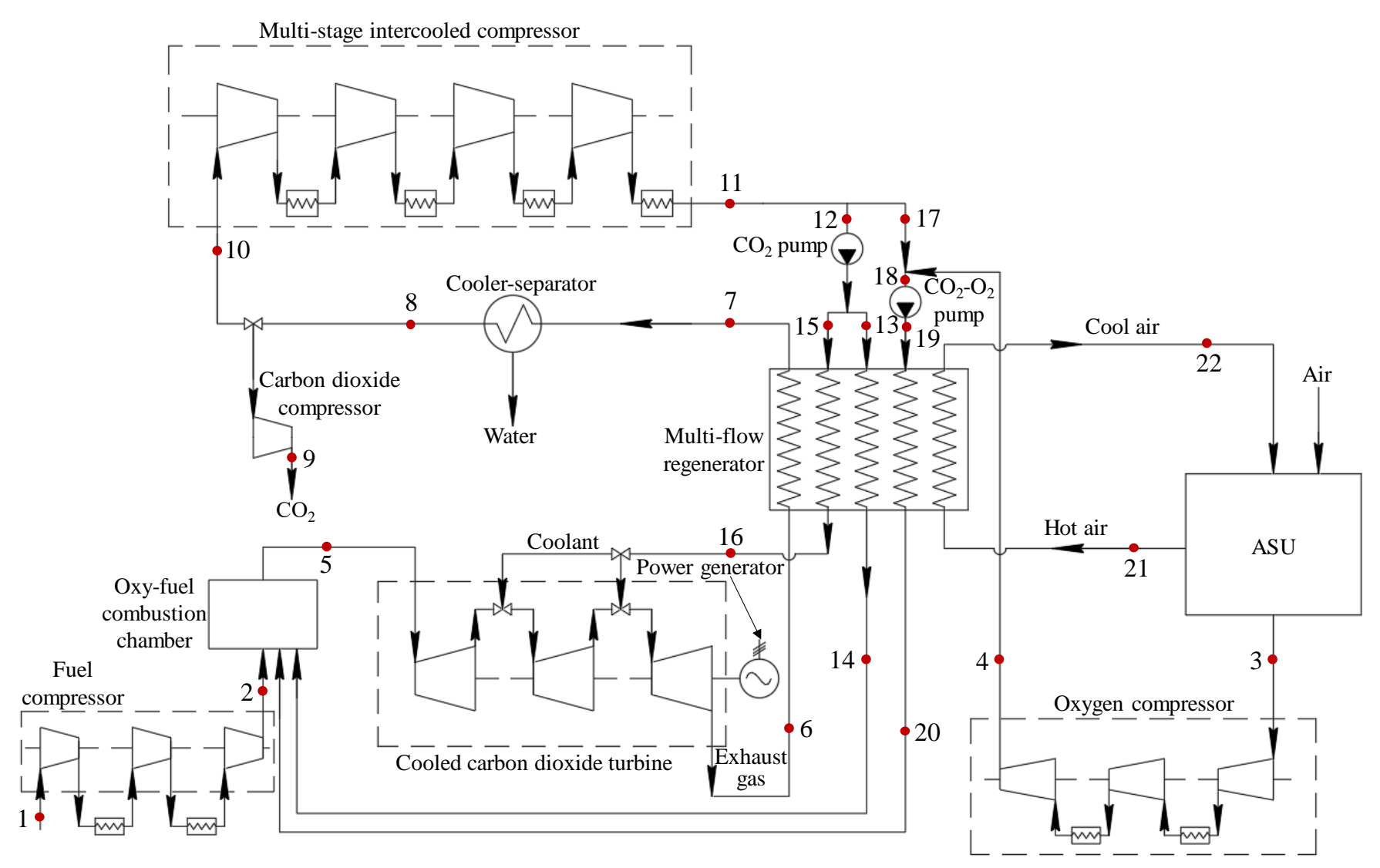

Figure 1. The Allam cycle with low-potential heat of the air used in the multi-flow regenerator.

The main flow enters the multi-stage intercooled compressor. The compressed flow is split in two and directed towards the entrances of $\mathrm{CO}_{2}$ and $\mathrm{CO}_{2}-\mathrm{O}_{2}$ pumps. The inlet flow of pump $\mathrm{CO}_{2}-\mathrm{O}_{2}$ is pre-mixed with compressed oxygen. The high-pressure pumps' exit flows enter the multi-flow regenerator and after heating, are directed toward to the combustor. The cycle is thus closed.

Table 1 summarizes the simulation input data for the oxy-fuel combustion power cycle. The data correspond to the optimization results presented in [26]. The fuel is pure methane, at an initial temperature and pressure of $15^{\circ} \mathrm{C}$ and $0.7 \mathrm{MPa}$, respectively. The fuel burns in the $96.5 \%$ pure oxygen produced in the ASU. The carbon dioxide sent for storage has modeled pressure and temperature of $10 \mathrm{MPa}$ and $28^{\circ} \mathrm{C}$, respectively [27].

Figure 2 shows the ASU producing oxygen for the combustor. Air is compressed in the axial compressor up to $0.7 \mathrm{MPa}$ and then is cooled down to $25^{\circ} \mathrm{C}$ and split into two flows. The main flow heads towards the nitrogen regenerators, and the other flow enters the oxygen regenerators. Downstream, the regenerator air is cooled to $-172{ }^{\circ} \mathrm{C}$, throttled, and supplied to the bottom rectifying column. In the column, the main air flow is separated at $0.55 \mathrm{MPa}$ into the nitrogen reflux (with 99\% nitrogen content) and the residue flow (with $62 \%$ nitrogen and $38 \%$ oxygen contents). Some air from the bottom column is supplied into the turbo-expander heat exchanger, where it is heated to $158{ }^{\circ} \mathrm{C}$ by the air flow. 
Table 1. Cycle simulation input data.

\begin{tabular}{|c|c|}
\hline Parameter & Value \\
\hline Turbine inlet temperature, ${ }^{\circ} \mathrm{C}$ & 1083 \\
\hline Turbine inlet pressure, $\mathrm{MPa}$ & 30 \\
\hline Turbine outlet pressure, $\mathrm{MPa}$ & 3 \\
\hline Turbine coolant temperature, ${ }^{\circ} \mathrm{C}$ & 200 \\
\hline $\mathrm{CO}_{2}$ compressor mass flow, $\mathrm{kG} / \mathrm{s}$ & 600 \\
\hline Atmospheric pressure, $\mathrm{MPa}$ & 0.1 \\
\hline Atmospheric temperature, ${ }^{\circ} \mathrm{C}$ & 15 \\
\hline Atmospheric humidity, \% & 60 \\
\hline Fuel type & $\mathrm{CH}_{4}$ \\
\hline Fuel temperature, ${ }^{\circ} \mathrm{C}$ & 15 \\
\hline Fuel pressure, $\mathrm{MPa}$ & 0.7 \\
\hline Fuel low heating value, $\mathrm{MJ} / \mathrm{kg}$ & 50 \\
\hline $\mathrm{CO}_{2}$ storage pressure, $\mathrm{MPa}$ & 10 \\
\hline Turbine isoentropic efficiency, $\%$ & 90 \\
\hline Multi-stage, intercooled compressor isoentropic efficiency, \% & 90 \\
\hline Fuel compressor isoentropic efficiency, $\%$ & 90 \\
\hline $\mathrm{O}_{2}$ compressor isoentropic efficiency, $\%$ & 90 \\
\hline $\mathrm{CO}_{2}$ compressor isoentropic efficiency, \% & 90 \\
\hline Pumps isoentropic efficiency, $\%$ & 90 \\
\hline Temperature difference in the multi-flow regenerator pinch point, ${ }^{\circ} \mathrm{C}$ & 5 \\
\hline Turbine, generator, and compressor mechanical efficiency, \% & 99 \\
\hline Pumps mechanical efficiency, $\%$ & 99 \\
\hline Power generator and electric motor mechanical efficiency, \% & 99 \\
\hline Working fluid temperature at the cooler-separator exit, ${ }^{\circ} \mathrm{C}$ & 55 \\
\hline Working fluid temperature at the compressor intercooler exit, ${ }^{\circ} \mathrm{C}$ & 30 \\
\hline Oxygen purity, $\%$ & 95.6 \\
\hline
\end{tabular}

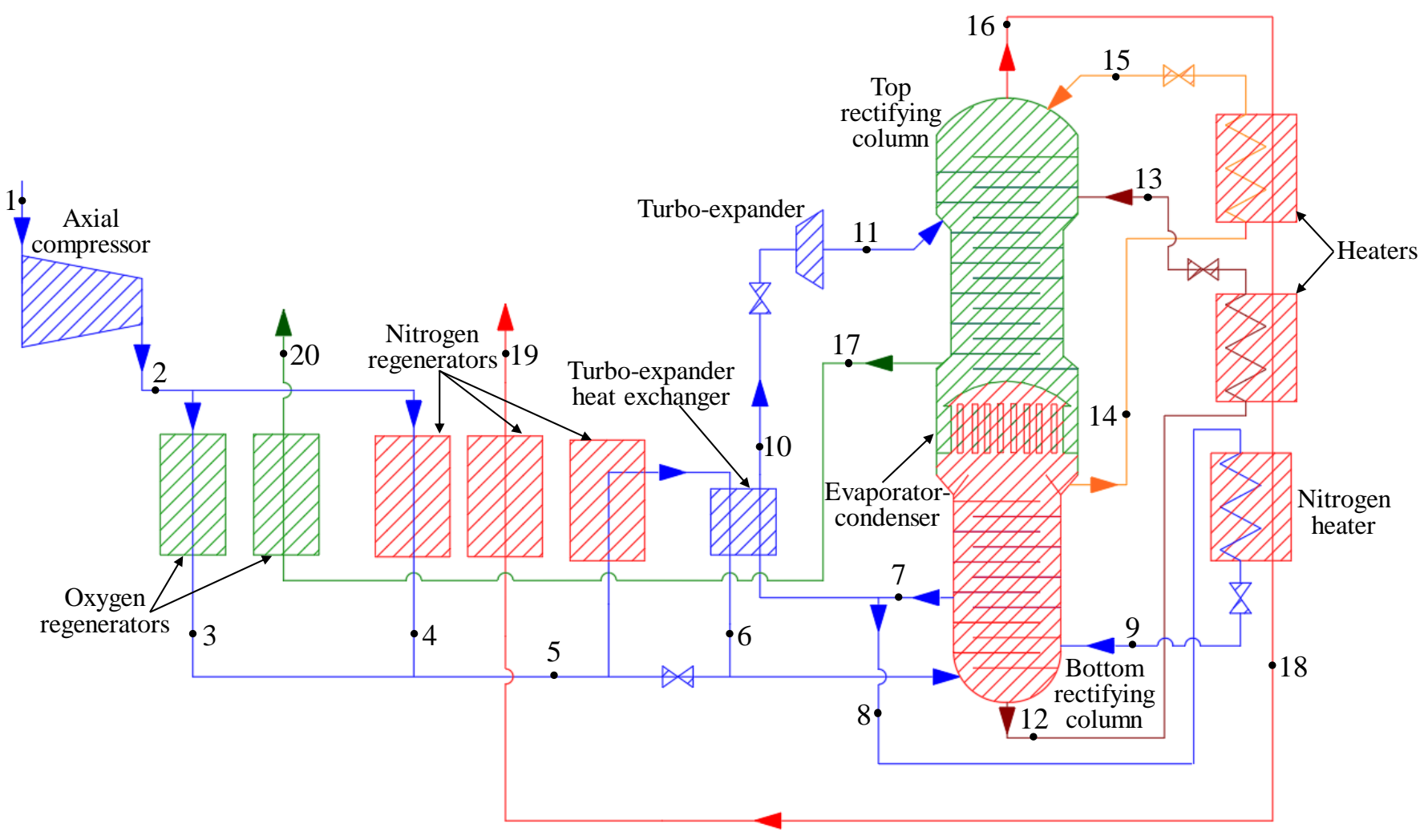

Figure 2. The low-pressure ASU. 
In the turbo-expander, air expands to the pressure of the top column, which is 0.13 $\mathrm{MPa}$, and enters the middle of the top column. At the same time, the residue flow and the nitrogen reflux produced in the bottom column heat the pure nitrogen exiting the top column in heaters, which is then throttled down to $0.13 \mathrm{MPa}$ and supplied to the top column. In the top column, the air is finally separated into $99 \%$ pure nitrogen and $95.6 \%$ oxygen. This separation is carried out via the rectification process. The flow parameters are summarized in Table 2.

Table 2. ASU flow parameters.

\begin{tabular}{|c|c|c|c|c|c|c|}
\hline \multirow{2}{*}{ Flow No } & \multirow{2}{*}{ Description } & \multicolumn{2}{|c|}{ Mole Fraction, $\%$} & \multirow{2}{*}{$\begin{array}{c}\text { Mass Flow Rate, } \\
\text { kg/s }\end{array}$} & \multirow{2}{*}{$\begin{array}{l}\text { Temperature, } \\
{ }^{\circ} \mathrm{C}\end{array}$} & \multirow{2}{*}{$\begin{array}{l}\text { Pressure } \\
\text { MPa }\end{array}$} \\
\hline & & $\mathrm{O}_{2}$ & $\mathbf{N}_{2}$ & & & \\
\hline 1 & Air compressor inlet & 0.209 & 0.791 & 1 & 15 & \\
\hline 2 & Air compressor out & & 0.1 & & & \\
\hline 3 & Air after oxygen regenerator & 0.209 & 0.791 & 1 & 30 & 0.589 \\
\hline 4 & Air after nitrogen regenerator & 0.209 & 0.791 & 0.205 & -172 & 0.574 \\
\hline 5 & Air after mixing & 0.209 & 0.791 & 0.795 & -172 & 0.574 \\
\hline 6 & $\begin{array}{l}\text { Air after turbo-expander heat } \\
\text { exchanger hot side }\end{array}$ & 0.209 & 0.791 & 1 & -172 & 0.574 \\
\hline 7 & Air after lower column & 0.209 & 0.791 & 0.115 & -113 & 0.574 \\
\hline 8 & Air in nitrogen heater & 0.209 & 0.791 & 0.248 & -173 & 0.574 \\
\hline 9 & Air from nitrogen heater & 0.209 & 0.791 & 0.011 & -173 & 0.574 \\
\hline 10 & $\begin{array}{l}\text { Air in turbo-expander from heat } \\
\text { exchanger cold side }\end{array}$ & 0.209 & 0.791 & 0.011 & -175.5 & \\
\hline 11 & Air after turbo-expander & 0.209 & 0.791 & 0.248 & -158 & 0.539 \\
\hline 12 & $\begin{array}{l}\text { Crude liquid oxygen from lower } \\
\text { column }\end{array}$ & 0.209 & 0.791 & 0.248 & -188 & 0.13 \\
\hline 13 & Crude liquid oxygen from heater & 0.38 & 0.62 & 0.404 & -174 & 0.56 \\
\hline 14 & Nitrogen reflux from lower column & 0.38 & 0.62 & 0.404 & -176.5 & 0.130 \\
\hline 15 & Nitrogen reflux from heater & 0.01 & 0.99 & 0.348 & -178 & 0.55 \\
\hline 16 & Nitrogen from upper column & 0.01 & 0.99 & 0.348 & -191.3 & 0.13 \\
\hline 17 & Oxygen from upper column & 0.99 & 0.01 & 0.790 & -193.8 & 0.125 \\
\hline 18 & Nitrogen from nitrogen heater & 0.956 & 0.044 & 0.210 & -178 & 0.135 \\
\hline 19 & Nitrogen output & 0.99 & 0.01 & 0.790 & -178 & 0.1175 \\
\hline 20 & Oxygen for Allam cycle & 0.99 & 0.01 & 0.790 & 26 & 0.0975 \\
\hline
\end{tabular}

\section{Methodology}

Thermodynamic studies of oxy-fuel combustion power cycles were carried out using the AspenONE code. The simulation flowchart is shown in Figure 3, along with the flow parameters in Table 3. The scheme included an oxy-fuel combustion chamber; a cooled carbon dioxide turbine; a multi-flow regenerator; a cooler-separator; a multi-stage, intercooled compressor; oxygen, fuel and carbon dioxide compressors; and $\mathrm{CO}_{2}$ and $\mathrm{CO}_{2-}$ $\mathrm{O}_{2}$ pumps. The thermo-physical performance of the operating fluid was calculated via the Peng-Robinson thermodynamic state equation. 


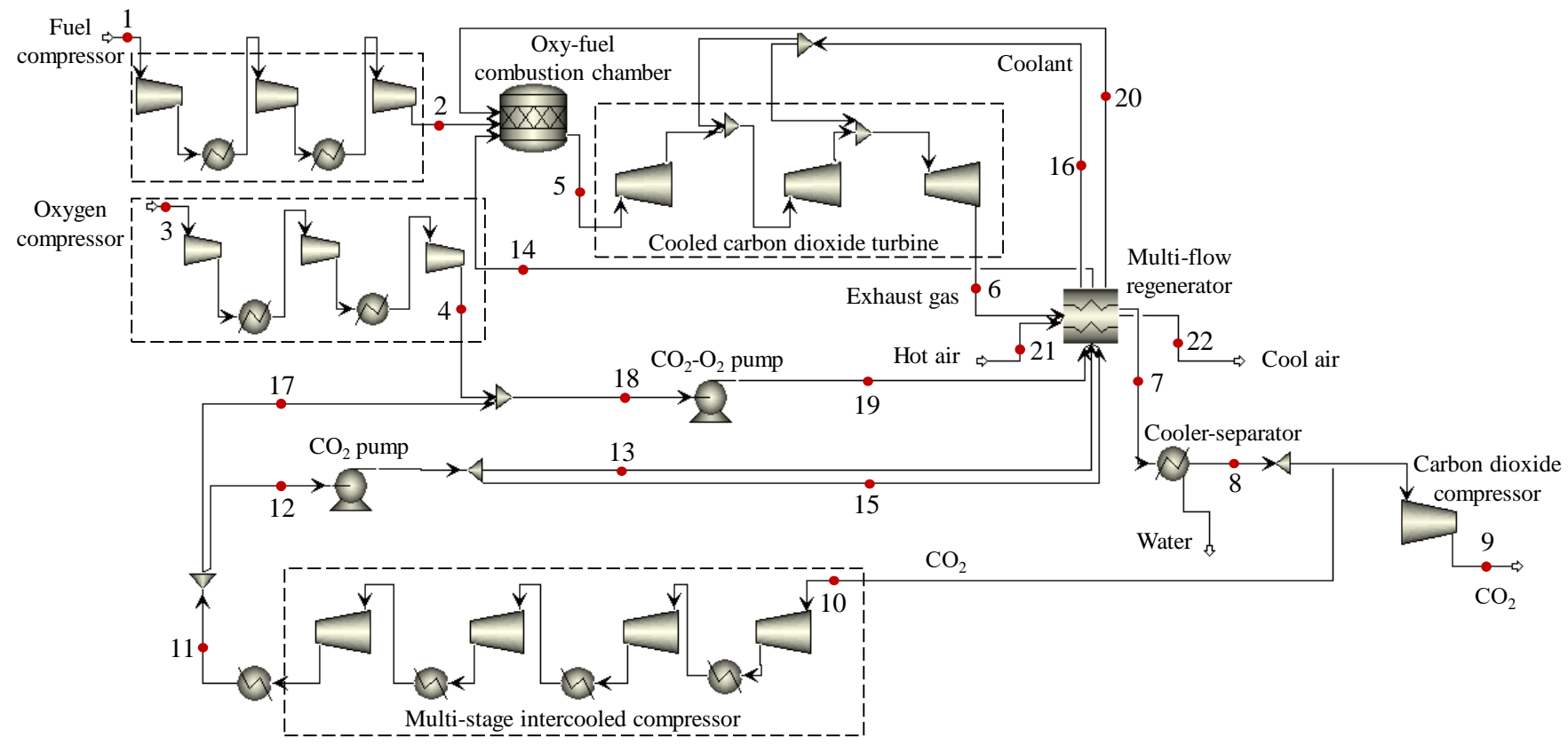

Figure 3. Simulation flowchart.

Table 3. Simulation flow parameters.

\begin{tabular}{|c|c|c|c|c|c|c|c|c|c|}
\hline \multirow{2}{*}{ Flow No } & \multirow{2}{*}{ Description } & \multicolumn{5}{|c|}{ Mass Fraction, $\%$} & \multirow{2}{*}{$\begin{array}{l}\text { Mass Flow } \\
\text { Rate, kg/s }\end{array}$} & \multirow{2}{*}{$\begin{array}{c}\text { Temperature, } \\
{ }^{\circ} \mathrm{C}\end{array}$} & \multirow{2}{*}{$\begin{array}{l}\text { Pressure, } \\
\text { MPa }\end{array}$} \\
\hline & & $\mathrm{CH}_{4}$ & $\mathrm{O}_{2}$ & $\mathbf{N}_{2}$ & $\mathrm{CO}_{2}$ & $\mathrm{H}_{2} \mathrm{O}$ & & & \\
\hline 1 & Fuel compressor inlet & 1 & - & - & - & - & 7.33 & 15 & 0.7 \\
\hline 2 & Fuel compressor outlet & 1 & - & - & - & - & 7.33 & 147.9 & 30 \\
\hline 3 & Oxygen compressor inlet & - & 1 & - & - & - & 29.3 & 26 & 0.1175 \\
\hline 4 & Oxygen compressor outlet & - & 1 & - & - & - & 29.3 & 190.6 & 8 \\
\hline 5 & Carbon dioxide turbine inlet & - & - & - & 0.974 & 0.026 & 618.8 & 1083 & 30 \\
\hline 6 & Carbon dioxide turbine outlet & & & - & 0.975 & 0.025 & 636.6 & 703.3 & 3 \\
\hline 7 & Cooler-separator inlet & - & - & - & 0.975 & 0.025 & 636.6 & 86 & 3 \\
\hline 8 & Cooler-separator outlet & - & - & - & 0.9975 & 0.0025 & 621.7 & 55 & 3 \\
\hline 9 & Carbon dioxide storage & - & - & - & 0.9975 & 0.0025 & 21.7 & 28 & 10 \\
\hline 10 & Multi-stage compressor inlet & - & _- & - & 0.9975 & 0.0025 & 600 & 55 & 3 \\
\hline 11 & Multi-stage compressor outlet & - & - & - & 0.9975 & 0.0025 & 600 & 30 & 8 \\
\hline 12 & $\mathrm{CO}_{2}$ pump inlet & - & - & - & 0.9975 & 0.0025 & 328.2 & 30 & 8 \\
\hline 13 & $\begin{array}{l}\text { Main } \mathrm{CO}_{2} \text { flow in multi-flow } \\
\text { regenerator }\end{array}$ & - & - & - & 0.9975 & 0.0025 & 310.4 & 74.3 & 30 \\
\hline 14 & $\begin{array}{l}\text { Main } \mathrm{CO}_{2} \text { flow from multi-flow } \\
\text { regenerator }\end{array}$ & - & - & - & 0.9975 & 0.0025 & 310.4 & 658.6 & 30 \\
\hline 15 & $\begin{array}{l}\text { Coolant flow in multi-flow } \\
\text { regenerator }\end{array}$ & - & - & - & 0.9975 & 0.0025 & 17.8 & 74.3 & 30 \\
\hline 16 & $\begin{array}{l}\text { Coolant flow from multi-flow } \\
\text { regenerator }\end{array}$ & - & - & - & 0.9975 & 0.0025 & 17.8 & 200 & 30 \\
\hline 17 & $\mathrm{CO}_{2}$ flow for mixing with $\mathrm{O}_{2}$ & - & - & - & 0.9975 & 0.0025 & 271.8 & 30 & 8 \\
\hline 18 & $\mathrm{CO}_{2}-\mathrm{O}_{2}$ pump inlet & - & 0.097 & - & 0.9 & 0.003 & 301.1 & 18.2 & 8 \\
\hline 19 & $\mathrm{CO}_{2}-\mathrm{O}_{2}$ pump outlet & - & 0.097 & - & 0.9 & 0.003 & 301.1 & 80.6 & 30 \\
\hline 20 & $\begin{array}{c}\mathrm{CO}_{2}-\mathrm{O}_{2} \text { at combustion chamber } \\
\text { inlet }\end{array}$ & - & 0.097 & - & 0.9 & 0.003 & 301.1 & 658.6 & 30 \\
\hline 21 & Air from ASU compressor & - & 0.233 & 0.767 & - & - & 139.03 & 241.4 & 0.589 \\
\hline 22 & Air from multi-flow regenerator & - & 0.233 & 0.767 & - & - & 139.03 & 79.3 & 0.589 \\
\hline
\end{tabular}

The heat flow simulation involved a few assumptions. Particularly, the hydraulic losses in the elements' connecting lines were assumed to be zero. Moreover, the combustion reaction was assumed to occur at a stoichiometric air-fuel ratio. The combustion products were water vapor and carbon dioxide:

$$
\mathrm{CH}_{4}+2 \cdot \mathrm{O}_{2}=2 \cdot \mathrm{H}_{2} \mathrm{O}+\mathrm{CO}_{2}+892 \mathrm{~kJ} / \mathrm{mol}
$$


An open cooling scheme of the gas turbine compartment was proposed for the estimation of turbine cooling losses. If the difference between working fluid and blade wall temperatures was less than $300{ }^{\circ} \mathrm{C}$, the convective cooling type was considered; otherwise, the film cooling type was adopted. In the model, the maximum acceptable average temperature of the blade metal outer surface was $850{ }^{\circ} \mathrm{C}$.

The distribution of cooling agent between the turbine compartments and the cooling loss analysis are both described in [5,28]. The method described in [29] was selected for the estimation of specific coolant mass flow, or cooling flow ratio. According to the chosen method, the cooling flow fraction for each vane/blade row was defined as follows:

$$
\Psi=\frac{K_{\text {cool }}}{1+B} \cdot \frac{\varepsilon_{0}-\varepsilon_{f}\left[1-\eta_{\text {int }}\left(1-\varepsilon_{0}\right)\right]}{\eta_{\text {int }} \cdot\left(1-\varepsilon_{0}\right)}
$$

To estimate the vane/blade cooling effectiveness $\varepsilon_{0}$ and the film-cooling effectiveness $\varepsilon_{f}$, the main flow and coolant temperatures were obtained from thermodynamic analysis of the oxy-fuel combustion cycle. A value of internal cooling efficiency $\eta_{\text {int }}$ equal to 0.7 was considered for the calculation, which represented the current level of the internal cooling technology. To evaluate the cooling flow factor $K_{\text {cool }}$, the values of the required geometry parameters were obtained from $1 \mathrm{D}$ thermal and aerodynamic calculation of the $\mathrm{CO}_{2}$ turbine flow path. To estimate the coefficient $B$, the metal and TBC Biot numbers, equal to 0.3 and 0.15 , correspondingly, were chosen, according to the recommendations in [29].

After determining the cooling flow factor for each turbine vane/blade row, the polytropic efficiency of the cooled stage was estimated with the method described in [30]:

$$
\eta_{o i . i}=\left(\frac{k-1}{k}\right) \cdot \frac{\log \left(\frac{P_{02}}{P_{01}}\right)}{\log \left(\frac{T_{02}}{T_{01}}\right)} .
$$

where $k$ was the specific heat ratio, $P_{01}$ was the total pressure at the stage inlet, $P_{02}$ was the total pressure at the stage outlet, $T_{01}$ was the total temperature at the stage inlet and $T_{02}$ was the total temperature at the stage outlet.

The regenerative heat exchanging system is considered to be a combined multi-flow heat exchanger. These assumptions result in some overestimations of data, but a more accurate analysis may be carried out by following the detailed design of the equipment.

The analysis of the multi-flow regenerator had the following conditions:

- The temperature difference in the pinch point was below $5^{\circ} \mathrm{C}$.

- The turbine cooling agent's temperature was $200^{\circ} \mathrm{C}$.

- The minimal compressed air temperature at the exit of the regenerator was $30^{\circ} \mathrm{C}$.

- The temperatures of all the heated flows, except that of the cooling agent flow at the regenerator exit, were equal.

The domestic power consumption for oxygen production was calculated with a developed model of cryogenic, low-pressure ASU. The model was created for the scheme presented on Figure 4a and allows evaluating influence of the following parameters upon ASU performance: oxygen mass flow rate $\left(G_{\mathrm{O} 2}, \mathrm{~kg} / \mathrm{s}\right)$, produced oxygen purity $\left(\mathrm{O}_{2}, \%\right)$, ambient air temperature $\left(\mathrm{t}_{\text {atm }},{ }^{\circ} \mathrm{C}\right)$, and compressor exit pressure ( $\left.\mathrm{P}_{\text {comp.out }}, \mathrm{MPa}\right)$. In this model, the compressor exit pressure corresponded with the assumed upper column pressure. The minimal and maximal oxygen purity degrees were assumed as $84 \%$ to 96 in this model, according to [31,32].

The ASU model was verified by the relationship of its power consumption and oxygen purity (Figure $4 \mathrm{~b}$ ). The calculated results were compared with the existing facility's statistical data [33]; the level of results convergence was acceptable. 


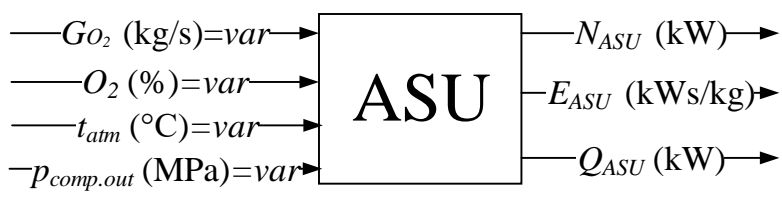

(a)

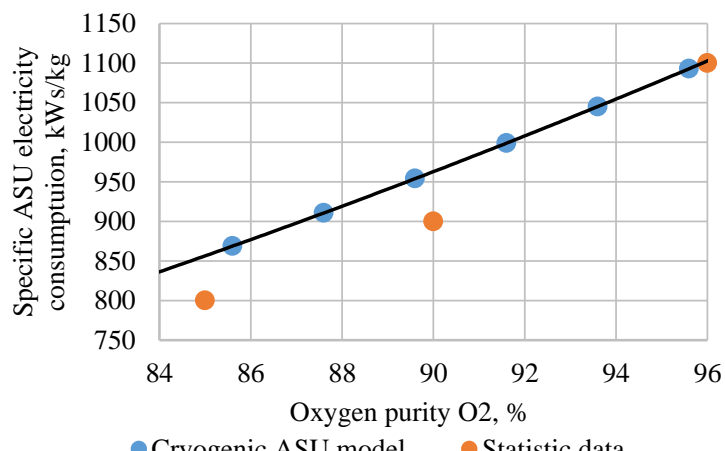

- Cryogenic ASU model Statistic data

(b)

Figure 4. ASU simulation model and results: (a) Model; (b) Dependence of the specific ASU electricity consumption on oxygen purity.

The ASU power consumption $N_{\mathrm{ASU}}(\mathrm{kW})$ may be calculated as follows:

$$
N_{A S U}=G_{O 2} \cdot e_{A S U}
$$

where $G_{\mathrm{O} 2}$ is oxygen mass flow rate, $\mathrm{kg} / \mathrm{s}$ and $\mathrm{e}_{\mathrm{ASU}}$ is the specific ASU electricity consumption, $\mathrm{kW} /(\mathrm{kg} / \mathrm{s})$.

The low potential heat $Q_{\mathrm{ASU}}(\mathrm{MW})$ carried by the ASU exit airflow was calculated as follows:

$$
Q_{A S U}=G_{\text {air }} \cdot c_{\text {p.air }} \cdot\left(T_{\text {air.out }}-T_{\text {air.in }}\right),
$$

where $G_{\text {air }}$ was air mass flow rate, $\mathrm{kg} / \mathrm{s} ; c_{\text {p.air }}$ was air specific heat capacity, $\mathrm{kJ} / \mathrm{kg} \cdot{ }^{\circ} \mathrm{C} ; T_{\text {air.out }}$ was the hot compressed air flow temperature from the ASU, ${ }^{\circ} \mathrm{C}$; and $T_{\text {air.in }}$ was the cold compressed air flow temperature to the ASU, ${ }^{\circ} \mathrm{C}$.

The developed models of the oxy-fuel combustion power cycle and ASU were used for the thermodynamic analysis. The calculation results were compared with the research data presented in [22]. In the case of an initial temperature and pressure of $1150{ }^{\circ} \mathrm{C}$ and $30 \mathrm{MPa}$ and a final pressure of $3 \mathrm{MPa}$, the cycle net efficiency mismatch was about $3.4 \%$. The reason for such divergence was the usage of different models of the ASU and cooled gas turbine.

\section{Results and Discussion}

The potential sources of the low-potential heat to be utilized may be evaluated via the initial temperature level and the amount of heat carried by a flow. The evaluation results are shown in Figures 5 and 6.

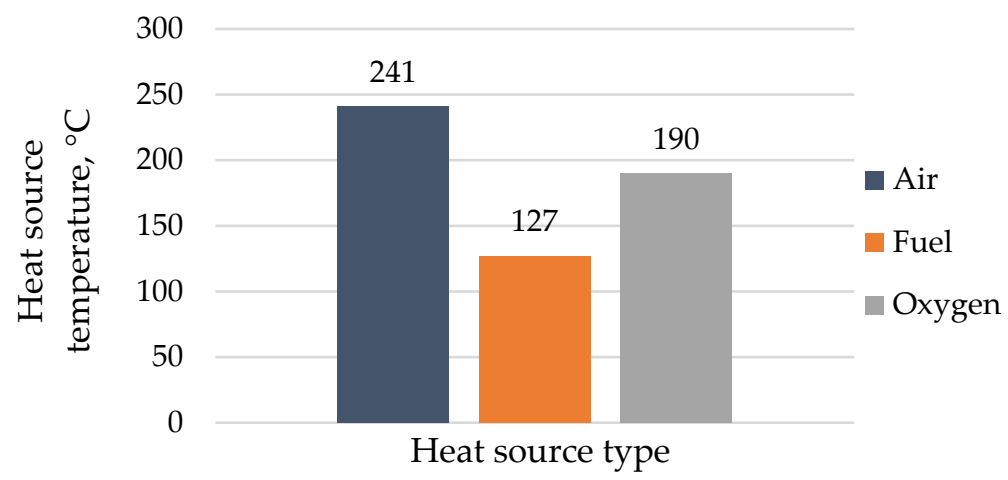

Figure 5. Temperatures of the low-heat sources. 


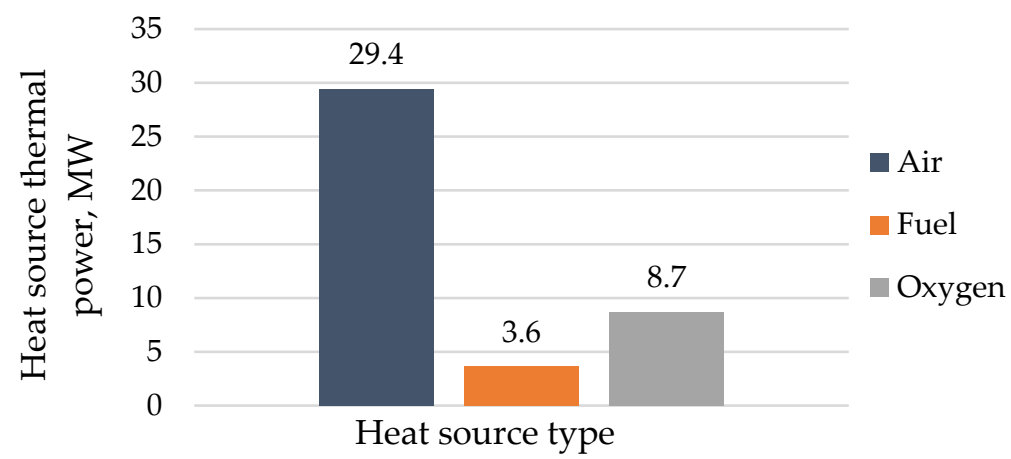

Figure 6. Thermal power of the low-heat sources.

The compressed air flow had a maximum temperature of $241^{\circ} \mathrm{C}$ (Figure 5) and a maximum thermal power of $29.4 \mathrm{MW}$. The oxygen flow potential was also high, with a temperature of $190^{\circ} \mathrm{C}$ and a thermal power of $8.7 \mathrm{MW}$. Contrary to this, the compressed fuel supplied to the intermediate coolers at $127^{\circ} \mathrm{C}$ and $3.6 \mathrm{MW}$ had relatively low thermal power. As such, the further analyses considered only two sources with maximal potential: the compressed air and the oxygen. The carbon monoxide flow that was compressed in the multi-stage, intercooled compressor was not considered as a low-potential heat source because of its very low temperature (about $55^{\circ} \mathrm{C}$ ).

In the basepoint cycle (Figure 1) the low-potential heat of the compressed air flow from the ASU was utilized as the main source of heat, but it seemed reasonable to evaluate the improvement in net efficiency via the described changes. For this reason, the model shown in Figure 7 differs in the absence of the air flow supplied to the multi-flow regenerator. This cycle is similar to the E-MATIANT cycle $[34,35]$.

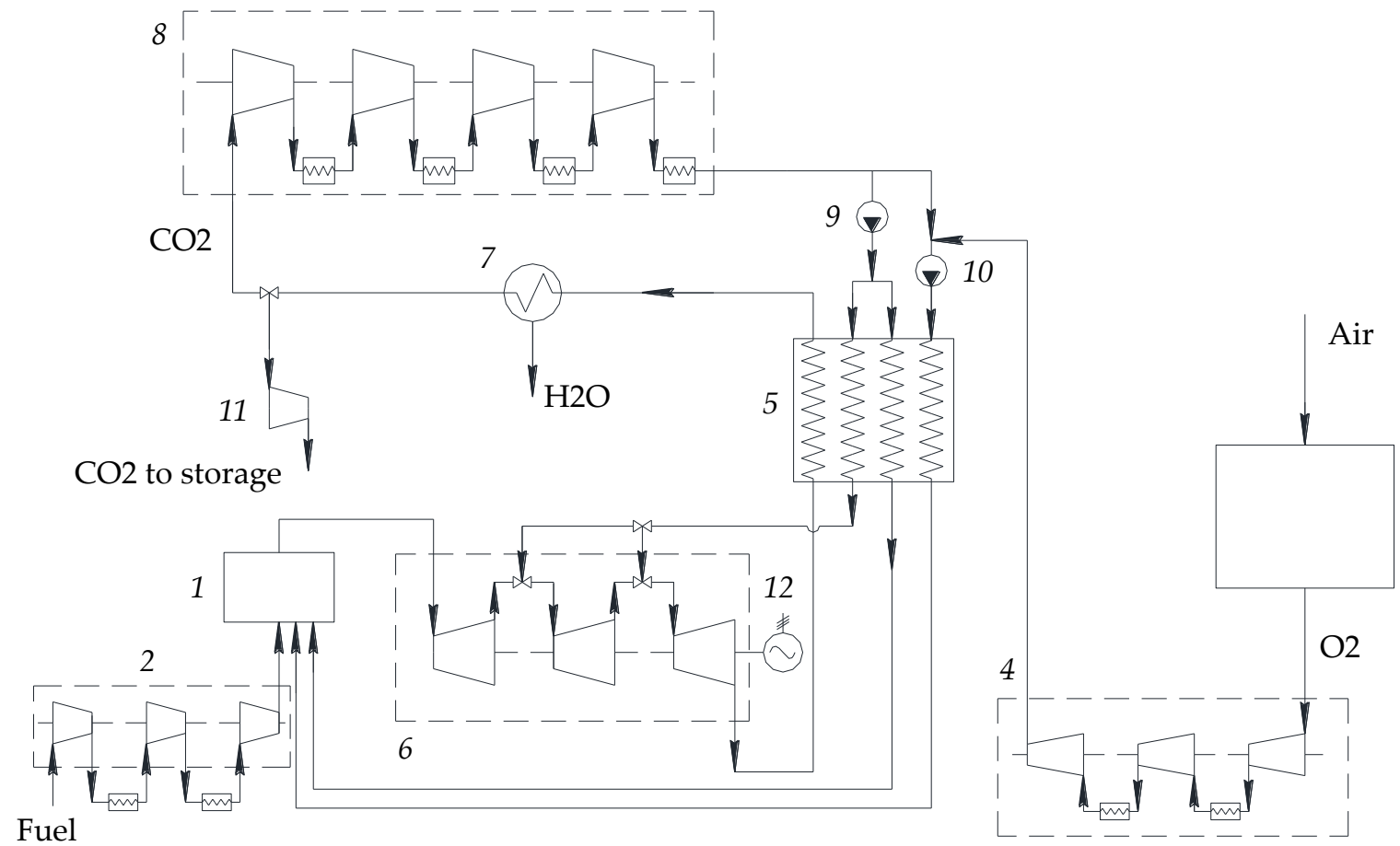

Figure 7. The Allam cycle that does not utilize the low-potential heat of the compressed air from the ASU in the regenerator.

The calculation results showed that the power unit's net efficiency was increased following the utilization of the compressed air's low-potential heat, from 47.7 to $51.2 \%$. The low efficiency of the cycle shown in Figure 7 was caused by the insufficiency of the 
heat produced by the turbine exhaust gas for heating the regenerator's cold flows. This was due to the difference in the thermal capacities of the heating and heated flows. The results were that the combustion chamber's inlet flows were cold, and the mean integral heat supply temperature of the cycle was lower.

The high air temperature in the ASU increases the compression losses and finally raises the energy consumption of the oxygen production process. As such, for the cycle shown in Figure 7, it was reasonable to evaluate the influence of air intercooling in the ASU upon the cycle's net efficiency. The analysis results showed that the two-stage intercooling process increased the cycle's net efficiency to $48.6 \%$, and the three-stage process increased it to $48.8 \%$.

Besides this, the optimal separation pressure that allowed minimal losses in oxygen production in one-stage intercooling was $0.26-0.28 \mathrm{MPa}$ (Figure 8), and the ASU compressor drive's specific energy consumption dropped from 1093 to $976 \mathrm{~kW} \mathrm{~s} / \mathrm{kg}$.

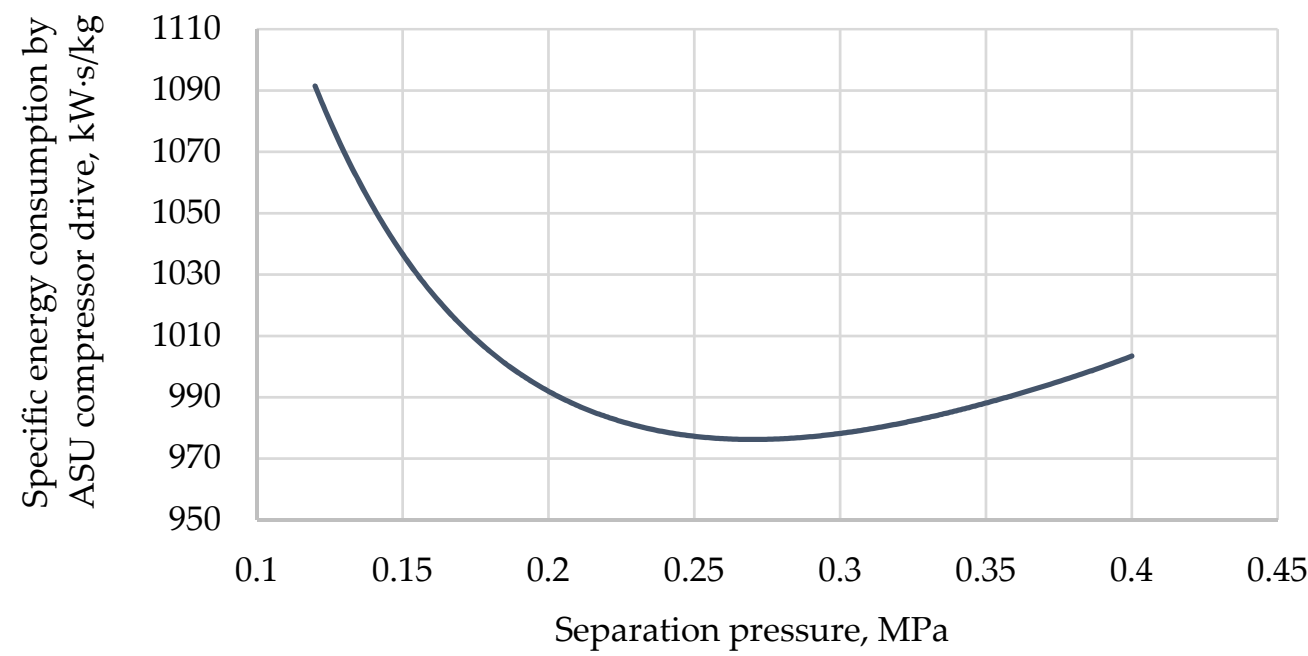

Figure 8. Dependence of the specific energy consumption of an ASU compressor drive with a single-stage intercooled compressor.

In two-stage intercooling, the first and second coolers' optimal pressures were $0.20-0.21 \mathrm{MPa}$ and $0.36 \mathrm{MPa}$, respectively (Figure 9). In this case, the specific energy consumption of the ASU compressor drive dropped to $941 \mathrm{~kW} \mathrm{~s} / \mathrm{kg}$.

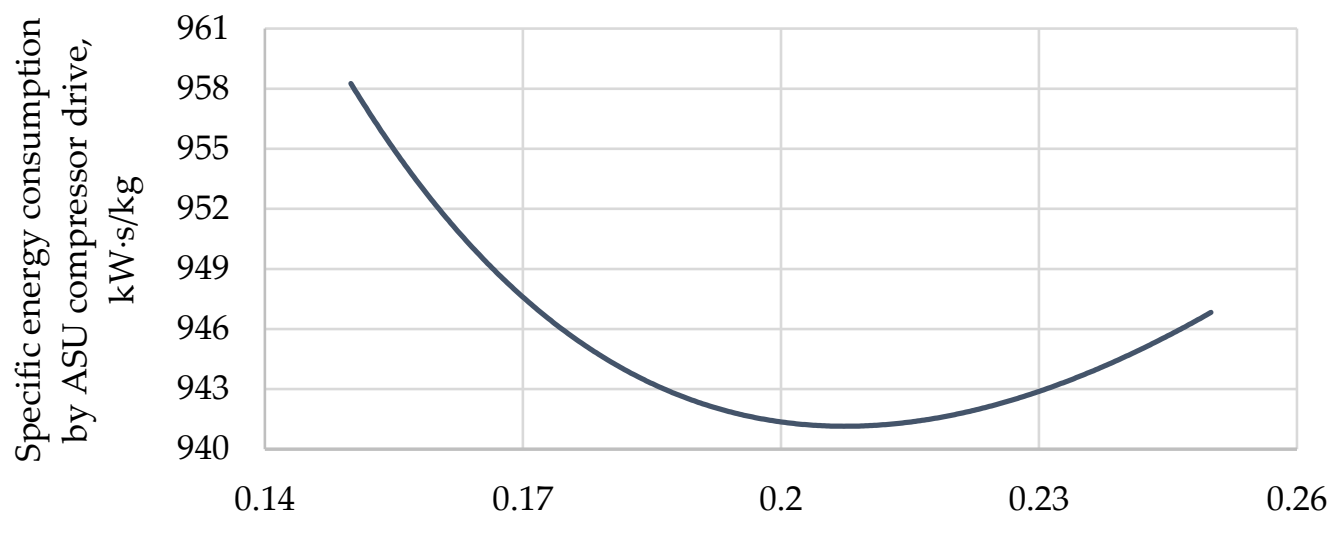

Separation pressure of the first compressor intercooling stage, $\mathrm{MPa}$

Figure 9. Dependence of the specific energy consumption of an ASU compressor drive with a two-stage intercooled compressor.

As such, the utilization of the heat of the ASU's compressed air in the multi-flow regenerator facilitated greater improvement in cycle efficiency (up to $51.2 \%$ ) than was 
achieved with the one-stage (up to $48.6 \%$ ) and two-stage (up to $48.6 \%$ ) processes of air intercooling with water.

The next assessment concerned the utilization of the compressed oxygen heat. An analysis of the cycle presented in Figure 1 showed that the regenerator did not require additional sources to the heat of the compressed air; as such, the oxygen heat should have been used for some other means: for example, in an additional cycle.

Figure 10 shows the Allam cycle utilizing the heat of the oxidizer in the Brayton cycle with recompression. The carbon dioxide heat carrier is employed because it balances the losses in the working fluid without any additional losses caused by the removal of some carbon dioxide flow from the main cycle.

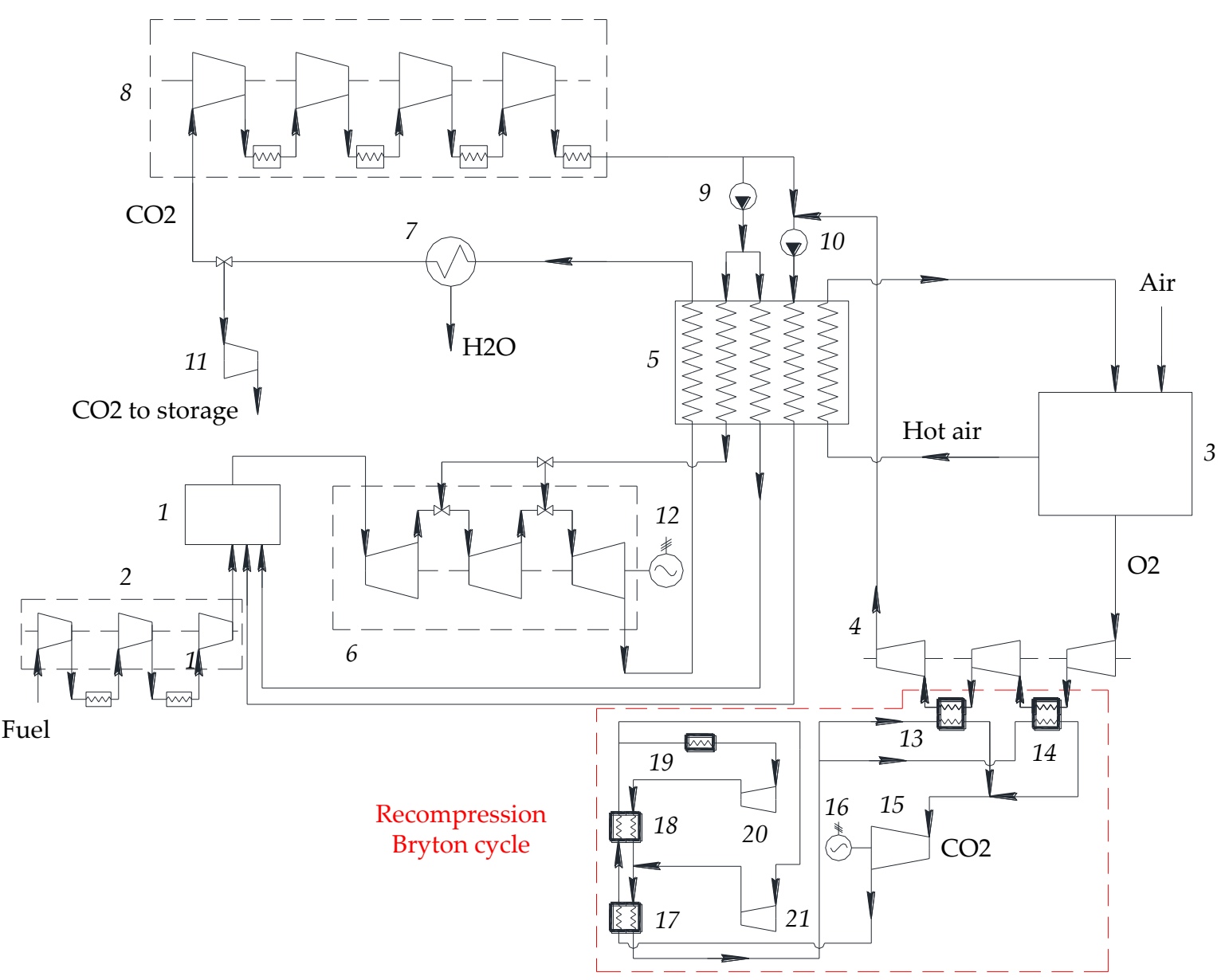

Figure 10. The Allam cycle utilizing the low-potential heat of compressed oxygen in a $\mathrm{S}-\mathrm{CO}_{2}$ recompression Brayton cycle.

The function of the additional carbon dioxide in the Brayton cycle with recompression is as follows: The heat sources are the oxygen compressor 4 inter-coolers 13 and 14, installed in parallel along the two operating fluid flows. The heat carrier flows of the heated carbon dioxide were mixed and directed into the turbine 15 inlet. The turbine drove electrical generator 16 . The exhaust gas of the turbine 15 was supplied to heat exchangers 17 and 18 for sequential cooling. Downstream of heat exchanger 18, the carbon dioxide flow split into two. The majority was supplied to the pre-cooler 19, which then reduced the workload of compressor 20. This flow was compressed in compressor 20, entered heat exchanger 18, was therein heated, and was then mixed with the second smaller flow. The smaller flow was transported directly to compressor 21. After mixing, the combined working fluid flow was heated in heat exchanger 17 and then supplied to heat exchangers 13 and 14 . As such, the cycle was closed. 
According to the modeling results, utilization of the low-potential heat of compressed oxygen in a $\mathrm{S}-\mathrm{CO}_{2}$ recompression Brayton cycle (Figure 10) increased the basepoint cycle (Figure 1) efficiency by $0.2 \%$. In turn, the specific investment cost, including the price of CCS for the basic configuration of the high-power Allam cycle, was equal to $1307.5 \$ / \mathrm{kW}$, according to [23]. The specific investment cost of the low-power, supercritical $\mathrm{CO}_{2}$ recompression Brayton cycle is in a range of 1400 to $1600 \$ / \mathrm{kW}$ (average value is $1500 \$ / \mathrm{kW}$ ), according to the research results presented in [36,37]. Therefore, the suggested modification of the Allam cycle, allowing for an increase in efficiency by $0.2 \%$, leads to an increase of the specific investment cost by $4.5 \%$. The total specific investment cost is equal to $1366.3 \$ / \mathrm{kW}$.

\section{Conclusions}

Accurate simulation models of oxy-fuel combustion power cycles were created using AspenONE software for thermodynamic analysis of the effects of utilizing various lowpotential energy sources. The simulation results in the structural-parametric optimization of prospective gas-burning, oxy-fuel combustion power cycles.

In oxy-fuel combustion power cycles operating on super-critical carbon dioxide, certain sources of low-potential heat are available. Secondary utilization of the compressed air that is used for oxygen production in the regenerative heat exchanger improves net efficiency by $3.5 \%$. The transferal of the compressed oxygen heat to the heat carrier in the Brayton cycle with recompression improves net efficiency by $0.2 \%$. As such, low-potential heat utilization may improve the net efficiency of the cycle, with initial temperature and pressure of $1083{ }^{\circ} \mathrm{C}$ and $30 \mathrm{MPa}$ and final pressure of $3 \mathrm{MPa}$, from 47.7 to $51.4 \%$.

When low-potential heat is not utilized, it is possible to increase the cycle efficiency by $1.1 \%$ via the optimization of intercooling pressure in the air separation unit's compressor; one-stage intercooling reduces the power consumption from 1093 to $976 \mathrm{~kW} \mathrm{~s} / \mathrm{kg}$ and two-stage intercooling from 1093 to $941 \mathrm{~kW} \mathrm{~s} / \mathrm{kg}$.

The cycle modification solutions reviewed in this paper describe the effective utilization of low-potential heat, which may facilitate an improvement in the efficiency of known oxy-fuel combustion power cycles.

Author Contributions: Conceptualization, A.R. and N.R.; methodology, A.R. and V.K.; software, V.K. and A.V.; validation, V.K. and A.V.; formal analysis, O.Z.; investigation, A.R., V.K., and A.V.; resources, O.Z.; data curation, A.V.; writing (original draft preparation), V.K.; writing (review and editing), A.R. and O.Z.; visualization, A.V.; supervision, A.R. and N.R.; project administration, A.R.; funding acquisition, O.Z. All authors have read and agreed to the published version of the manuscript.

Funding: This study was conducted by the Moscow Power Engineering Institute and was financially supported by the Ministry of Science and Higher Education of the Russian Federation (project no. FSWF-2020-0020).

Institutional Review Board Statement: Not applicable.

Informed Consent Statement: Not applicable.

Data Availability Statement: Not applicable.

Conflicts of Interest: The authors declare no conflict of interest.

\section{References}

1. Mauleon, I. Economic Issues in Deep Low-Carbon Energy Systems. Energies 2020, 13, 4151. [CrossRef]

2. Eitan, A.; Rosen, G.; Herman, L.; Fishhendler, I. Renewable Energy Entrepreneurs: A Conceptual Framework. Energies 2020, 13, 2554. [CrossRef]

3. Climent Barba, F.; Sanchez, G.M.D.; Segui, B.S.; Darabkhani, H.G.; Anthony, E.J. A Technical Evaluation, Performance Analysis and Risk Assessment of Multiple Novel Oxy-Turbine Power Cycles with Complete $\mathrm{CO}_{2}$ Capture. J. Clean. Prod. 2016, 133, 971-985. [CrossRef]

4. Hamadeh, H.; Toor, S.Y.; Douglas, P.L.; Sarathy, S.M.; Dibble, R.W.; Croiset, E. Techno-Economic Analysis of Pressurized Oxy-Fuel Combustion of Petroleum Coke. Energies 2020, 13, 3463. [CrossRef] 
5. Rogalev, A.; Kindra, V.; Osipov, S.; Rogalev, N. Thermodynamic Analysis of the Net Power Oxy-Combustion Cycle. In Proceedings of the 13-th European Conference on Turbomachinery Fluid dynamics \& Thermodynamics, Lausanne, Switzerland, 8-12 April 2019.

6. Yang, H.J.; Kang, D.W.; Ahn, J.H.; Kim, T.S. Evaluation of Design Performance of the Semi-Closed Oxy-Fuel Combustion Combined Cycle. J. Eng. Gas Turb. Power 2012, 134, 111702. [CrossRef]

7. Rogalev, A.; Kindra, V.; Zonov, A.; Rogalev, N.; Agamirov, L. Evaluation of Bleed Flow Precooling Influence on the Efficiency of the E-MATIANT Cycle. Mech. Mech. Eng. 2018, 22, 593-602. [CrossRef]

8. Allam, R.; Martin, S.; Forrest, B.; Fetvedt, J.; Lu, X.; Freed, D.; Brown, G.; Sasaki, T.; Itoh, M.; Manning, J. Demonstration of the Allam Cycle: An Update on the Development Status of a High Efficiency Supercritical Carbon Dioxide Power Process Employing Full Carbon Capture. Energy Procedia. 2016, 114, 5948-5966. [CrossRef]

9. Rodríguez Hervas, G.; Petrakopoulou, F. Exergoeconomic Analysis of the Allam Cycle. Energ. Fuel. 2019, 33, 7561-7568. [CrossRef]

10. Zaryab, S.A.; Scaccabarozzi, R.; Martelli, E. Advanced Part-Load Control Strategies for the Allam Cycle. Appl. Therm. Eng. 2020, 168, 114822. [CrossRef]

11. Sasaki, T.; Itoh, M.; Maeda, H.; Tominaga, J.; Saito, D.; Niizeki, Y. Development of turbine and combustor for a semi-closed recuperated Brayton cycle of supercritical carbon dioxide. In Proceedings of the ASME Power Conference, Charlotte, NC, USA, 26-30 June 2017; American Society of Mechanical Engineers: New York, NY, USA, 2017; p. V001T02A008.

12. Rogalev, A.; Rogalev, N.; Kindra, V.; Vegera, A.; Zonov, A. Multi-stream heat exchanger for oxy-fuel combustion power cycle. AIP Conf. Proceedings 2021, 2323, 050001.

13. Scaccabarozzi, R.; Gatti, M.; Martelli, E. Thermodynamic optimization and part-load analysis of the NET Power Cycle. Energy Procedia. 2017, 114, 551-560. [CrossRef]

14. Martins, F.; Felgueiras, C.; Smitkova, M.; Caetano, N. Analysis of fossil fuel energy consumption and environmental impacts in European countries. Energies 2019, 12, 964. [CrossRef]

15. Warner, K.J.; Jones, G.A. The 21-st century coal question: China, India, development, and climate change. Atmosphere 2019, 10, 476. [CrossRef]

16. Allam, R.J.; Palmer, M.R.; Brown, G.W., Jr.; Fetvedt, J.; Freed, D.; Nomoto, H.; Itoh, M.; Okita, N.; Jones, C., Jr. High efficiency and low cost of electricity generation from fossil fuels while eliminating atmospheric emissions, including carbon dioxide. Energy Procedia 2013, 37, 1135-1149. [CrossRef]

17. Hume, S. Performance evaluation of a supercritical $\mathrm{CO}_{2}$ power cycle coal gasification plant. In Proceedings of the 5-th International Symposium of Supercritical $\mathrm{CO}_{2}$ Power Cycles, San Antonio, TX, USA, 28-31 March 2016.

18. Weiland, N.; Shelton, W.; White, C.; Gray, D. Performance baseline for direct-fired sCO2 cycles. In Proceedings of the 5-th International Symposium of Supercritical CO 2 Power Cycles, San Antonio, TX, USA, 28-31 March 2016.

19. Weiland, N.; White, C. Techno-economic analysis of an integrated gasification direct-fired supercritical $\mathrm{CO}_{2}$ power cycle. Fuel 2018, 212, 613-625. [CrossRef]

20. Zhao, Y.; Zhao, L.; Wang, B.; Zhang, S.; Chi, J.; Xiao, Y. Thermodynamic analysis of a novel dual expansion coal-fueled direct-fired supercritical carbon dioxide power cycle. Appl. Energy 2018, 217, 480-495. [CrossRef]

21. Zhao, Y.; Wang, B.; Chi, J.; Xiao, Y. Parametric study of a direct-fired supercritical carbon dioxide power cycle coupled to coal gasification process. Energy Convers. Manage. 2018, 156, 733-745. [CrossRef]

22. Scaccabarozzi, R.; Gatti, M.; Martelli, E. Thermodynamic Analysis and Numerical Optimization of the NET Power OxyCombustion Cycle. Appl. Energy 2016, 178, 505-526. [CrossRef]

23. Rogalev, A.; Grigoriev, E.; Kindra, V.; Rogalev, N. Thermodynamic Optimization and Equipment Development for a High Efficient Fossil Fuel Power Plant with Zero Emissions. J. Clean. Prod. 2019, 236, 117592. [CrossRef]

24. Rogalev, A.; Rogalev, N.; Kindra, V.; Osipov, S. Dataset of Working Fluid Parameters and Performance Characteristics for the Oxy-Fuel, Supercritical $\mathrm{CO}_{2}$ Cycle. Data Brief 2019, 27, 104682. [CrossRef]

25. Zhu, Z.; Chen, Y.; Wu, J.; Zhang, S.; Zheng, S. A Modified Allam Cycle without Compressors Realizing Efficient Power Generation with Peak Load Shifting and $\mathrm{CO}_{2}$ Capture. Energy 2019, 174, 478-487. [CrossRef]

26. Fernandes, D.; Wang, S.; Xu, Q.; Buss, R.; Chen, D. Process and Carbon Footprint Analyses of the Allam Cycle Power Plant Integrated with an Air Separation Unit. Clean Technol. 2019, 1, 325-340.

27. Gibbins, J.; Chalmers, H. Carbon Capture and Storage. Energy Policy 2008, 36, 4317-4322. [CrossRef]

28. Rogalev, A.; Rogalev, N.; Kindra, V.; Komarov, I.; Zlyvko, O. Research and Development of the Oxy-Fuel Combustion Power Cycles with $\mathrm{CO}_{2}$ Recirculation. Energies 2021, 14, 2927. [CrossRef]

29. Wilcock, R.C.; Young, J.B.; Horlock, J.H. The effect of turbine blade cooling on the cycle efficiency of gas turbine power cycles. J. Eng. Gas Turbine Power 2005, 127, 109-120. [CrossRef]

30. Thorbergsson, E.; Grönstedt, T. A thermodynamic analysis of two competing mid-sized oxyfuel combustion combined cycles. J. Energy 2016, 2438431. [CrossRef]

31. Kerry, F.G. Industrial Gas Handbook: Gas Separation and Purification, 1st ed.; CRC Press: Boca Raton, FL, USA, $2007 ;$ p. 550.

32. Ebrahimi, A.; Meratizaman, M.; Reyhani, H.A.; Pourali, O.; Amidpour, M. Energetic, Exergetic and Economic Assessment of Oxygen Production from Two Columns Cryogenic Air Separation Unit. Energy 2015, 90, 1298-1316. [CrossRef]

33. Van der Ham, L.V.; Kjelstrup, S. Exergy analysis of two cryogenic air separation processes. Energy 2010, 35, 4731-4739. [CrossRef] 
34. Mathieu, P.; Dubuisson, R.; Houyou, S.; Nihart, R. New concept of $\mathrm{CO}_{2}$ removal technologies in power generation, combined with fossil fuel recovery and long term $\mathrm{CO}_{2}$ sequestration. In Proceedings of the ASME Turbo Expo 2000: Power for Land, Sea, and Air, Munich, Germany, 8-11 May 2000; American Society of Mechanical Engineers: New York, NY, USA, 2000; p. V002T04A011.

35. Mathieu, P. Towards the hydrogen era using near-zero $\mathrm{CO}_{2}$ emissions energy systems. Energy 2004, 29, 1993-2002. [CrossRef]

36. Carlson, M.D.; Middleton, B.M.; Ho, C.K. Techno-economic comparison of solar-driven SCO2 Brayton cycles using component cost models baselined with vendor data and estimates. In Energy Sustainability; American Society of Mechanical Engineers: New York, NY, USA, 2017; Volume 57595, p. V001T05A009.

37. Rao, Z.; Xue, T.; Huang, K.; Liao, S. Multi-objective optimization of supercritical carbon dioxide recompression Brayton cycle considering printed circuit recuperator design. Energy Convers. Manag. 2019, 201, 112094. [CrossRef] 